University of South Florida

DIGITAL COMMONS

Digital Commons @ University of

@ UNIVERSITY OF SOUTH FLORIDA

South Florida

6-15-1995

\title{
Analysis of Ocean Color Components Within Stratified and Well- Mixed Waters of the Western English Channel
}

\author{
Herschel T. Hochman \\ University of South Florida \\ John J. Walsh \\ University of South Florida, jwalsh@marine.usf.edu \\ Kendall L. Carder \\ University of South Florida, kcarder@marine.usf.edu
}

\section{A. Sournia}

Observatoire Oceanologique de Roscoff

Frank E. Muller-Karger

University of South Florida, carib@marine.usf.edu

Follow this and additional works at: https://digitalcommons.usf.edu/msc_facpub

Part of the Marine Biology Commons

\section{Scholar Commons Citation}

Hochman, Herschel T.; Walsh, John J.; Carder, Kendall L.; Sournia, A.; and Muller-Karger, Frank E., "Analysis of Ocean Color Components Within Stratified and Well-Mixed Waters of the Western English Channel" (1995). Marine Science Faculty Publications. 76.

https://digitalcommons.usf.edu/msc_facpub/76

This Article is brought to you for free and open access by the College of Marine Science at Digital Commons @ University of South Florida. It has been accepted for inclusion in Marine Science Faculty Publications by an authorized administrator of Digital Commons @ University of South Florida. For more information, please contact digitalcommons@usf.edu. 


\title{
Analysis of ocean color components within stratified and well-mixed waters of the western English Channel
}

\author{
Herschel T. Hochman, John J. Walsh, and Kendall L. Carder \\ Department of Marine Science, University of South Florida, St. Petersburg \\ A. Sournia \\ Observatoire Oceanologique de Roscoff, Laboratoire de Geologie du Museum, Paris
}

\section{Frank E. Muller-Karger}

Department of Marine Science, University of South Florida, St. Petersburg

\begin{abstract}
In situ pigment and dissolved organic carbon (DOC) data from two distinct hydrographic regions of the western English Channel are used to explore the possible marine DOC contamination of the past satellite estimates of phytoplankton biomass. To compare with field measurements, the individual spectral contributions of DOC, pigments, and water to the total diffuse attenuation coefficient, $K_{\mathrm{par}}$, are summed on a quantum basis within stratified waters near Plymouth, England; and for the spectrally averaged diffuse attenuation coefficient, $K_{d}$, on an energy basis within tidally mixed waters near Roscoff, France. In addition, coastal zone color scanner (CZCS) images from 1979 to 1986 were used to compute DOC concentrations for comparison with in situ values. Our analysis suggests that almost $50 \%$ of the color signal of satellite-sensed pigments may be attributed to absorption by marine colored DOC (CDOC) within the English Channel. These results compare favorably to the in situ DOC measurements off Plymouth, but not to off-Roscoff measurements, suggesting that there may be more CDOC in the stratified waters and more nonabsorbing DOC in the tidally mixed waters.
\end{abstract}

\section{Introduction}

Our previous studies of the particulate and dissolved components of remotely sensed color signals of coastal ecosystems [Carder et al., 1989; Walsh et al., 1992] indicated that as much as $50 \%$ of the apparent chlorophyll biomass sensed by the coastal zone color scanner (CZCS) may be an artifact. Within some case II waters impacted by river effluent this situation may be due to the presence of colored dissolved organic carbon (CDOC) of mainly terrestrial origin [Hochman et al., 1994]. For example, the spring increment of total dissolved organic carbon (DOC) in the southern North Sea, offshore of the Rhine delta, is at least $1.3 \mathrm{mg} \mathrm{DOC} \mathrm{L}^{-1}$ within 2 months [Duursma, 1963]. With present satellite algorithms such an increment of DOC in the southern North Sea would be interpreted as a spurious chlorophyll bloom. Since the Texel light ship observations [Duursma, 1963] are located at the 33 practical salinity unit (psu) surface isopleth during March-May, based on longterm data [International Council for the Exploration of the Sea, 1962], these spring increments of DOC may be influenced by terrestrial sources.

In waters of the western English Channel, however, salinities of $>\mathbf{3 4 . 8}$ psu suggest that influence of the freshwater yellow substances, that is, CDOC, on satellite detection of phytoplankton biomass may be negligible here [Holligan et al., 1983], compared to the adjacent estuarine waters [Laane, 1982; Mantoura and Woodward, 1983; Wafar et al.,

Copyright 1995 by the American Geophysical Union.

Paper number $95 \mathrm{~J}$ C00464.

0148-0227/95/95JC-00464\$05.00
1989]. Thus we wished to explore the consequences of mainly marine sources of CDOC, which might not covary with the phytoplankton pigments over time, thus confounding the "standard" CZCS algorithms [Gordon et al., 1983]. Accordingly, we selected two different regions of the western English Channel (areas E and B of Figure 1), where seasonal time series of in situ pigments, DOC, total light attenuation (Table 1), and phytoplankton species' composition and size fraction [Holligan and Harbour, 1977; Sournia et al., 1987; Davies et al., 1992] have been collected over the past 30 years.

Station E data from seasonally stratified waters above the $70-\mathrm{m}$ isobath off Plymouth, England (near $50^{\circ} 02^{\prime} \mathrm{N}, 4^{\circ} 22^{\prime} \mathrm{W}$ ) exhibit distinct winter-spring blooms of diatoms. These waters generate in situ chlorophyll (chl) biomasses of $2-5 \mathrm{mg}$

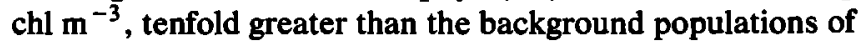
picoplankton and nannoplankton [Jordan and Joint, 1984; Davies et al., 1992], like similar waters of the Celtic Sea and the Mid-Atlantic Bight [Malone et al., 1983; Joint et al., 1986], and were apparently sensed by the CZCS with little interannual variation during March-April (Plate 1). A priori, a greater error might be expected in the winter months since the CZCS atmospheric path is longer and there may be more difficulty in retrieving accurate data.

Unlike the Celtic Sea and Mid-Atlantic Bight regions, however, since 1966, summer blooms [Dixon and Holligan, 1989; Le Corre et al., 1993; Partensky and Sournia, 1986] of

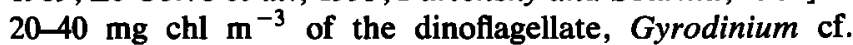
aureolum have been recorded. The patchiness of their populations leads to much larger daily and interannual variability of "pigments" sampled by the CZCS around 


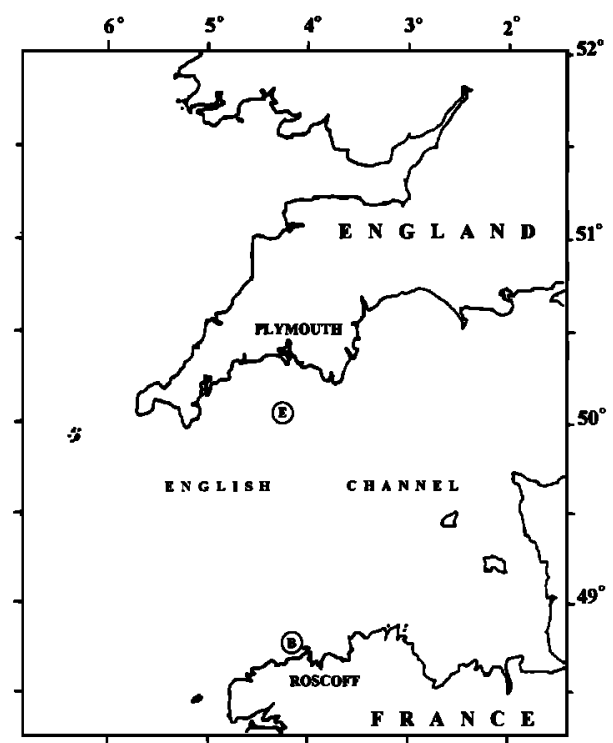

Figure 1. The coastal zone color scanner (CZCS) sampling grid (circles) in the English Channel around Stations $\mathrm{E}$ and B, located near Plymouth, England, and Roscoff, France.

station E during June and July (Plate 2). As a consequence, we will find that time series of CZCS images compiled over 1979-1986 and of in situ observations over 1975-1990 for this region both display (Figure 2) a larger range of summer and fall values off Plymouth, England, than in tidally mixed waters off Roscoff, France (Figure 3).

Above the $30-\mathrm{m}$ isobath off Roscoff at station B (near $48^{\circ} 44^{\prime} \mathrm{N}, 3^{\circ} 57^{\prime} \mathrm{W}$ ) diatoms prevail most of the year; $G$. aureolum is not found in these waters [Holligan et al., 1984; Klein and Sournia, 1987]. Off Roscoff in situ chlorophyll values of $1-2 \mathrm{mg}$ chl m $\mathrm{m}^{-3}$ persisted throughout April to October during 1979-1980, when the concurrent DOC data were collected (Table 1). During other years, for example, 1985 , the onset of the Roscoff spring bloom may be delayed a month, with values of $1-5 \mathrm{mg} \mathrm{chl} \mathrm{m}^{-3}$ found during May-June, a July-August minimum of $0.5-1 \mathrm{mg} \mathrm{chl} \mathrm{m}^{-3}$,

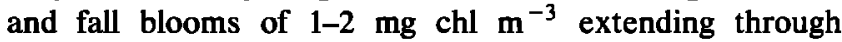
November [Sournia et al., 1987].

Within these constraints of interannual variability we first estimate the individual contributions of water, CDOC, and pigments to light attenuation over depth, time, and spectral wavelength. Off Plymouth their sum, the computed total diffuse attenuation coefficient on a quantum basis, $K_{\mathrm{par}}$, is compared to the means of monthly observed $K_{\text {par }}$ values over 400-700 nm (Table 1) within the upper $10 \mathrm{~m}$ around station E [Pingree et al., 1976; Holligan and Harbour, 1977; Jordan and Joint, 1984].

Since the light attenuation at station B was instead estimated with a radiometer from the vertical profiles of downwelling irradiance at four wavelengths of 400, 443, 520, and $550 \mathrm{~nm}$ [Sournia et al., 1987], the spectrally weighted mean diffuse attenuation coefficient, $K_{d}$, was averaged over 400 $550 \mathrm{~nm} . K_{d}$ was then computed over the same wavelengths from the DOC and pigment measurements for comparison with the mean monthly observations over the upper $25 \mathrm{~m}$ at station B.

Finally, the monthly discrepancies (Table 2) between the CZCS and in situ estimates of pigment (e.g., Figures 2 and 3) are used to compute the equivalent DOC for comparison with observations. Presumably, as a result of either more secretion of DOC during or more plankton decomposition after, the larger primary production in shallow waters off France [Wafar et al., 1983; Martin-Jezequel, 1983], DOC stocks off Roscoff range seasonally from 1.1 to $2.2 \mathrm{mg}$ DOC $\mathrm{L}^{-1}$ [Wafar et al., 1984], compared to 0.6-1.1 $\mathrm{mg} \mathrm{DOC} \mathrm{L}^{-1}$ off Plymouth [Banoub and Williams, 1973]. Both groups of analysts used the same wet oxidation technique for measurement of DOC [Menzel and Vaccaro, 1964].

\section{Methods}

We used an approach similar to that taken in the biooptical model of Sathyendranath and Platt [1988] to consider

Table 1. The Seasonal Variation of In Situ DOC, $K_{\mathrm{par}}, K_{d}$, and Pigments

\begin{tabular}{|c|c|c|c|c|c|c|}
\hline & \multicolumn{3}{|c|}{$\begin{array}{l}\text { Plymouth } \\
\text { Station E }\end{array}$} & \multicolumn{3}{|c|}{$\begin{array}{c}\text { Roscoff } \\
\text { Station B }\end{array}$} \\
\hline & $\underset{\mathrm{mg} \mathrm{L}^{-1}}{\mathrm{DOC}}$ & $\mathrm{K}_{\mathrm{par}}, \mathrm{m}^{-1}$ & $\begin{array}{l}\text { Pigment, } \\
\mathrm{mg} \mathrm{m}^{-3}\end{array}$ & $\mathrm{mg} \mathrm{L}^{-1}$ & $\mathrm{~K}_{\mathrm{d}}, \mathrm{m}^{-1}$ & $\begin{array}{l}\text { Pigment, } \\
\text { mg m }^{-3}\end{array}$ \\
\hline Jan. & $\cdots$ & $\cdots$ & $\cdots$ & $\cdots$ & $\cdots$ & $\cdots$ \\
\hline Feb. & 0.75 & 0.17 & 0.40 & 1.48 & 0.06 & 0.49 \\
\hline March & 0.59 & 0.12 & 1.00 & 1.82 & 0.06 & 0.95 \\
\hline April & 0.75 & 0.16 & 2.17 & 1.39 & 0.10 & 1.35 \\
\hline May & 0.91 & 0.11 & 1.20 & 1.42 & 0.08 & 1.43 \\
\hline June & 1.00 & 0.08 & 1.21 & 1.33 & 0.08 & 1.75 \\
\hline July & 0.76 & 0.14 & 0.83 & 1.86 & 0.06 & 1.00 \\
\hline Aug. & 0.85 & 0.32 & 10.2 & 2.00 & 0.08 & 1.85 \\
\hline Sep. & 1.12 & 0.15 & 1.03 & 1.42 & 0.06 & 1.38 \\
\hline Oct. & 0.71 & 0.12 & 0.45 & 2.02 & 0.07 & 1.38 \\
\hline Nov. & 0.66 & 0.10 & 0.45 & 1.37 & $\cdots$ & 0.70 \\
\hline Dec. & $\cdots$ & 0.08 & 0.30 & 1.40 & $\cdots$ & 0.80 \\
\hline
\end{tabular}

Three center dots indicate no data. $K_{\mathrm{par}}$ for Station $\mathrm{E}$ is the total diffuse attenuation coefficient over $400-700 \mathrm{~nm}$, while $K_{d}$ is the spectrally averaged diffuse attenuation coefficient over the upper $25 \mathrm{~m}$ for the 400-550 $\mathrm{nm}$ band for Station B. After Banoub and Williams [1973], Pingree et al. [1976], Holligan and Harbour [1977], Jordan and Joint [1984], Wafar et al. [1984], Sournia et al. [1987], and Davies et al. [1992]. 


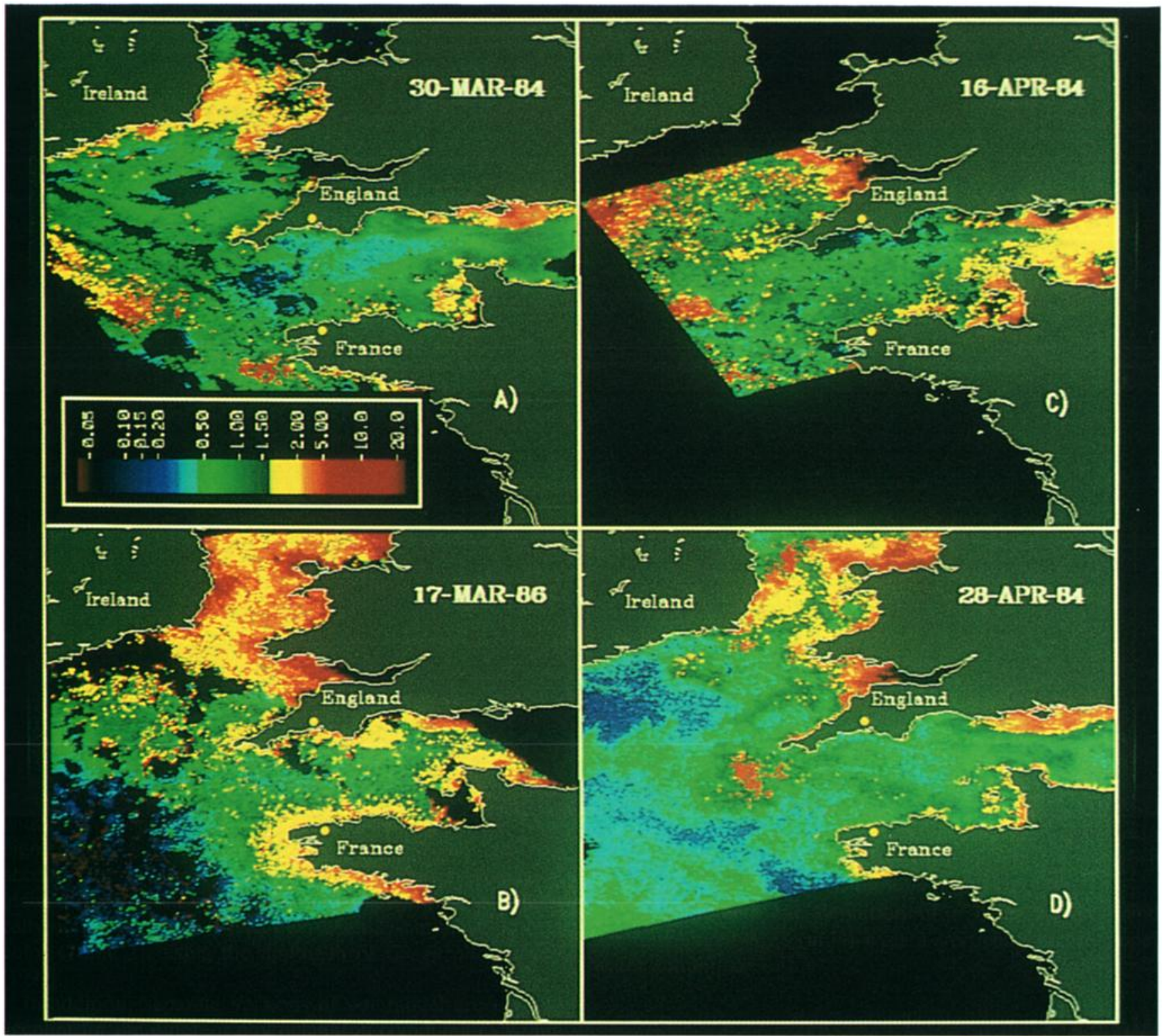

Plate 1. CZCS daily images of the English Channel for the spring of 1984-1986. Warm colors (yellow, orange, and red) represent a combination of high pigment and CDOC concentrations; blue color represents clearer waters.

both the irradiance path length and the spectral attenuation of light as a function of depth, since the respective validation data for $K_{\text {par }}$ and $K_{d}$ are expressed over the upper $10 \mathrm{~m}$ (Plymouth) and $25 \mathrm{~m}$ (Roscoff) of the water column. Since we wished to examine the temporal covariance of the constituents of $K_{\text {par }}$ and $K_{d}$ we averaged over 25-nm bandwidths the separate contributions of water, CDOC, and pigments to light attenuation each month. Similarly, to account for seasonal changes in the spectral quality of incoming radiation, we estimate the incident photosynthetically active radiation (PAR) over each $25-\mathrm{nm}$ bandwidth of color (Table 3), using the approach of Gregg and Carder [1990].

In addition, separate versions of our model are used to account for the different phytoplankton communities within stratified and permanently mixed waters off Plymouth and Roscoff, respectively. We employ differences in the spectral shape of the specific absorption coefficients, $a_{p h}^{*}$, of phytoplankton $\left(\mathrm{m}^{2}(\mathrm{mg} \mathrm{chl})^{-1}\right)$. We assumed representative spectral mean values of 0.0323 and $0.0202 \mathrm{~m}^{2}(\mathrm{mg} \mathrm{chl})^{-1}$ obtained from stratified (stations 1 and 2) and well-mixed (stations $\mathrm{B}$ and $\mathrm{H}$ ) waters of the Gulf of Maine [Hoepffner and Sathyendranath, 1992], since the annual cycles of elements and functional groups of phytoplankton there [Walsh et al., 1987] are similar to those in the western English Channel, except for the $G$. aureolum blooms.

We begin with the definition of a mean spectral and depth-averaged $K_{\text {par }}\left(\mathrm{m}^{-1}\right)$ over a vertically mixed upper water column as

$$
K_{\mathrm{par}}=-\ln T(z) / z
$$

with $T(z)$, the transmittance at depth $z$, defined as 


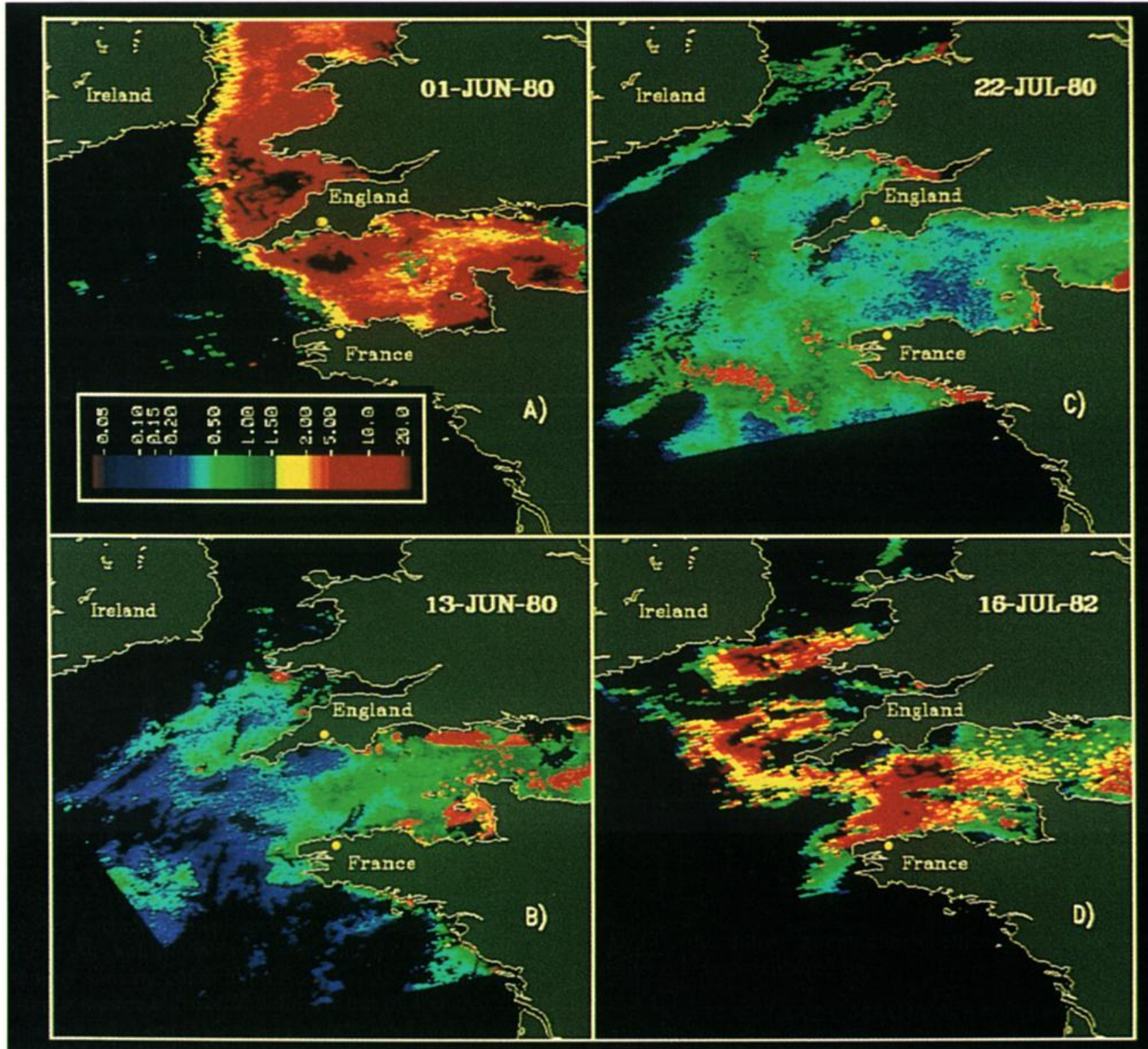

Plate 2. CZCS daily images of the English Channel for the summer of 1980 and 1982 . The color bar is the same as that of Plate 1.

$$
\begin{aligned}
T= & \operatorname{PAR}(z) / \operatorname{PAR}(0)=h c \int_{400}^{700} 1 / \lambda E(\lambda) \\
& \cdot \exp -\left[K_{W}(\lambda)+K_{Y}(\lambda)+K_{C}(\lambda)\right] z d \lambda \\
& \cdot\left[h c \int_{400}^{700} 1 / \lambda E(\lambda) d \lambda\right]^{-1}
\end{aligned}
$$

where $E(\lambda)$ is the spectral downwelling irradiance crossing the sea surface at local apparent noon during every month (Table 3). Values of $E(\lambda)$ were calculated for clear skies (remote sensing conditions) from Gregg and Carder [1990] using a marine aerosol, a default wind of $4-6 \mathrm{~m} \mathrm{~s}^{-1}$, and a visibility of $23 \mathrm{~km}$ (Table 3 ). The relationship $h c / \lambda$ converts $E(\lambda)$ from a photon power to a photon flux, with $h$ as Planck's constant and $c$ is the speed of light. The depth $z$ is 10 or $25 \mathrm{~m}$, while the individual components of diffuse attenuation $\left(\mathrm{m}^{-1}\right)$ are $K_{W}(\lambda)$ due to water, $K_{Y}(\lambda)$ of CDOC, and $K_{C}(\lambda)$ of chlorophyll and other pigments. A similar computation is made for $K_{d}$, where

$$
\begin{aligned}
T= & \int_{400}^{550} E(\lambda) \exp -\left[K_{W}(\lambda)+K_{Y}(\lambda)+K_{C}(\lambda)\right] z d \lambda \\
& \cdot\left(\int_{400}^{550} E(\lambda) d \lambda\right)^{-1} .
\end{aligned}
$$

$K_{W}(\lambda)$, the diffuse attenuation coefficient for clear ocean waters, is approximated by

$$
K_{W}(\lambda)=\left[a_{w}(\lambda)+b_{w}(\lambda)\right] / \cos \theta=c_{w}(\lambda) / \cos \theta
$$

where $a_{w}(\lambda), b_{w}(\lambda)$, and $c_{w}(\lambda)$ are the absorption, scattering, and beam attenuation coefficients for optically pure water, obtained from Morel and Prieur [1977]. Cos $\theta$ is the 
cosine of the solar zenith angle in seawater, taken to be 0.83 [Sathyendranath et al., 1989] for an average skylight.

$K_{Y}(\lambda)$, the diffuse attenuation coefficient for colored dissolved organic material, is evaluated from

$$
K_{Y}(\lambda)=a_{y s}(\lambda) / \cos \theta
$$

where $a_{y s}(\lambda)$ is the absorbance due to CDOC. Over similar ranges of $0.7-2.2 \mathrm{mg} \mathrm{DOC} \mathrm{L}^{-1}$ and $1-15 \mathrm{mg} \mathrm{chl} \mathrm{m} \mathrm{m}^{-3}$ off Japan, Okami et al. [1982] found that $a_{y s}(\lambda)$ could be related to total DOC by

$$
a_{y s}(\lambda)=(-0.17+0.36 \mathrm{DOC}) \exp [-0.0167(\lambda-380)]
$$

in which $0.0167\left(\mathrm{~nm}^{-1}\right)$ determines the spectral slope of $a_{y s}(\lambda)$.

From this relationship the ratio of $\mathrm{CDOC} / \mathrm{DOC}$ is not constant [Walsh et al., 1992]; below a value of approximately $0.47 \mathrm{mg} \mathrm{DOC} \mathrm{L}^{-1}, a_{y s}(\lambda)=0$; that is, the remaining DOC would be nonabsorbing, as reflected by the negative intercept, and therefore not affect the color signal. At a concentration of $\sim 1 \mathrm{mg}$ DOC $\mathrm{L}^{-1}$, the CDOC specific absorption at $380 \mathrm{~nm}, a_{\text {doc }}^{*}(380)$, is $\sim 0.19 \mathrm{~L} \mathrm{mg}^{-1} \mathrm{~m}^{-1}$ from (5), where $a_{y s}(\lambda)=a_{\mathrm{doc}}^{*}(\lambda)$ DOC. In contrast, at $443 \mathrm{~nm}$ and $\sim 1 \mathrm{mg} \mathrm{DOC} \mathrm{L}^{-1}, a_{\mathrm{doc}}^{*}(443)$ is $\sim 0.07 \mathrm{~L} \mathrm{mg}^{-1} \mathrm{~m}^{-1}$. This is similar to that of $0.15 \mathrm{~L} \mathrm{mg} \mathrm{m}^{-1}$ found at $375 \mathrm{~nm}$ on the Louisiana shelf [Carder et al., 1989].

$K_{C}(\lambda)$, the diffuse attenuation coefficient for phytoplankton, is computed from

$$
K_{C}(\lambda)=\left[\left(a_{p h}^{*}(\lambda) C\right)+b_{b c}(\lambda)\right] / \cos \theta
$$

where $a_{p h}^{*}(\lambda)$ is the specific absorption coefficient $\left[\mathrm{m}^{2}\right.$ (mg chl $)^{-1}$ ] of phytoplankton at different wavelengths from the two Gulf of Maine regions [Hoepffner and Sathyendranath, 1992], $C$ is the concentration ( $\mathrm{mg} \mathrm{m}^{-3}$ ) of pigments (chloro-

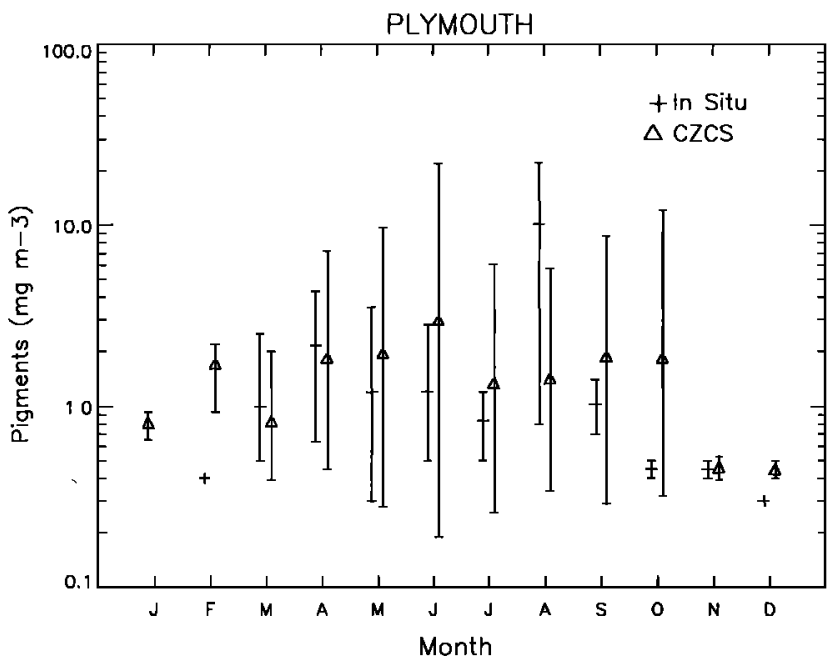

Figure 2. The yearly range and averages for the (plus) in situ and (triangle) CZCS data from Station E off Plymouth, England. The time series of CZCS images was compiled over 1979-1986, while the in situ measurements were taken over 1975-1990 (data from Holligan and Harbour [1977], Pingree et al. [1976], Davies et al. [1992], and Jordon and Joint [1984]).

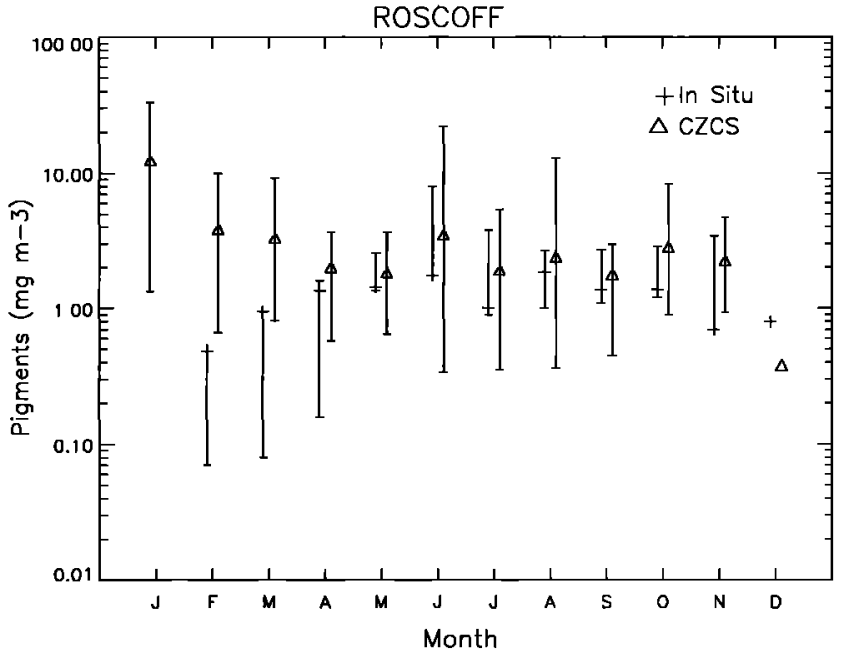

Figure 3. The yearly range and averages for the (plus) in situ and (triangle) CZCS data from Station B off Roscoff, France. The time series of CZCS images was compiled over 1979-1986, while the in situ measurements were taken over 1979-1985 (data from Wafar et al. [1984] and Sournia et al. [1987]).

phyll + phaeopigments), and $b_{b c}(\lambda)$ is the backscattering (per meter) by phytoplankton [Gordon and Morel, 1983].

CZCS pigment values from 64 of the best available images covering the time period 1979-1986 were used, for example, Plates 1 and 2. Each image represented a single day, where any particular month is usually represented by a few images. There were months during the various years, however, for which no data were available. Where several days images were used for any particular month, the data was averaged. The 4-km pigment data from NASA's Goddard Space Flight Center [Feldman et al., 1989; Muller-Karger, 1992] were averaged over $300 \mathrm{~km}^{2}$ around stations $E$ and $B$ (Figure 1). The standard algorithm of Gordon et al. [1983] was used to estimate these pigment values from the water-leaving radiances.

In situ measurements $(n=75)$ of pigments (Tables 1 and 2) were similarly averaged over just the upper $10 \mathrm{~m}$ (Plymouth) and $25 \mathrm{~m}$ (Roscoff) of the water column for the months in which the data were available. The CZCS could only detect pigment over the first optical depth at $443 \mathrm{~nm}$, for example, a mean $\mathrm{K}^{-1}$ of $\sim 7.7 \mathrm{~m}$ off Plymouth. Since the waters off Roscoff are well-mixed, these values of in situ pigments represent the average of the $25-\mathrm{m}$ water column.

Utilizing the $\mathrm{CZCS}$ aerosol component computed from the $670 \mathrm{~nm}$ channel, little or no pattern was seen with scales indicative of suspended sediments within either the Plymouth or Roscoff regions. The seston content of seawater off Roscoff was 0.5-1.0 mg dry weight (dw) $\mathrm{L}^{-1}$ during 1985 [Sournia et al., 1987], similar to oceanic surface waters [Morel and Prieur, 1977].

We thus define the difference between the remotely sensed and in situ values of pigment as the apparent excess pigment (AEP) ( $\mathrm{mg} \mathrm{m}^{3}$ ), which may instead represent light absorbed by CDOC, since sediments are considered to be a negligible component in the western English Channel. The absorption $a_{y s}\left(\mathrm{~m}^{-1}\right)$ attributed to $\mathrm{CDOC}$ is 
Table 2. The Seasonal Variation Over the Upper 10 and $25 \mathrm{~m}$ of Mean In Situ and Coastal Zone Color Scanner-sensed Pigments at Stations E and B Respectively

\begin{tabular}{|c|c|c|c|c|c|c|}
\hline & \multicolumn{3}{|c|}{$\begin{array}{l}\text { Plymouth } \\
\text { Station E }\end{array}$} & \multicolumn{3}{|c|}{$\begin{array}{c}\text { Roscoff } \\
\text { Station B }\end{array}$} \\
\hline & In Situ & $\underset{\mathrm{mg} \mathrm{m}^{-3}}{\mathrm{CZCS}}$ & $\underset{\mathrm{mg} \mathrm{m}^{-3}}{\mathrm{AEP}}$ & In Situ & $\underset{\mathrm{mg} \mathrm{m}^{-3}}{\mathrm{CZCS}}$ & $\underset{\mathrm{mg} \mathrm{m}^{-3}}{\mathrm{AEP}}$ \\
\hline Jan. & $\cdots$ & 0.81 & $\cdots$ & $\cdots$ & 12.5 & $\ldots$ \\
\hline Feb. & 0.40 & 1.72 & 1.32 & 0.49 & 3.89 & 3.40 \\
\hline March & 1.00 & 0.83 & -0.17 & 0.95 & 3.33 & 2.38 \\
\hline April & 2.17 & 1.85 & -0.32 & 1.35 & 2.03 & 0.68 \\
\hline May & 1.20 & 1.97 & 0.77 & 1.43 & 1.85 & 0.42 \\
\hline June & 1.21 & 3.01 & 1.80 & 1.75 & 3.52 & 1.77 \\
\hline July & 0.83 & 1.35 & 0.52 & 1.00 & 1.93 & 0.93 \\
\hline Aug. & 10.2 & 1.42 & -8.79 & 1.85 & 2.39 & 0.54 \\
\hline Sep. & 1.03 & 1.89 & 0.86 & 1.38 & 1.79 & 0.41 \\
\hline Oct. & 0.45 & 1.86 & 1.41 & 1.38 & 2.84 & 1.46 \\
\hline Nov. & 0.45 & 0.46 & 0.01 & 0.70 & 2.28 & 1.58 \\
\hline Dec. & 0.30 & 0.45 & 0.15 & 0.80 & 0.38 & -0.40 \\
\hline
\end{tabular}

The apparent excess pigment (AEP) $\left(\mathrm{mg} \mathrm{m}^{-3}\right)$ is the difference between the in situ and satellite observations; three center dots indicate no data.

$$
a_{y s}=\operatorname{AEP} x a_{p h(443)}^{*}
$$

where $a_{p h(443)}^{*}$ is now the mean specific absorption coefficient at $443 \mathrm{~nm}$ for both the stratified and well-mixed waters, that is, $0.062\left[\mathrm{~m}^{2}\right.$ (mg chl) $\left.{ }^{-1}\right]$. We chose this band, since it is the peak absorption band for phytoplankton and one of the primary channels of the CZCS. The equivalent DOC concentration is then calculated using (5).

To test our model, we examined concurrent measured

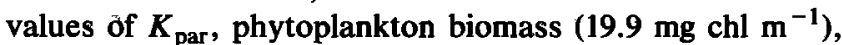
and DOC (1.7 $\left.\mathrm{mg} \mathrm{L}^{-1}\right)$ on the same day at mid-Channel during July 1981 [Holligan et al., 1984]. Our computed value of $0.56 \mathrm{~m}^{-1}$ is very close to their observed value of $0.54 \mathrm{~m}^{-1}$ over the upper $10 \mathrm{~m}$.

\section{Results}

During the spring and summer blooms off Plymouth, for example, phytoplankton pigments contribute as much as $30-65 \%$ of the attenuation of visible light (Figure 4). The large August contribution of phytoplankton is attributed to blooms of $G$. aureolum [Jordan and Joint, 1984]. As a result of the smaller DOC stocks off Plymouth than off Roscoff
(Table 1), CDOC contributes at most $15 \%$ of the light attenuation, with a 1-month time lag after the seasonal peaks of algal biomass. During fall and winter periods, water itself accounts for as much as $\mathbf{8 6 \%}$ of the color signal.

Although the chlorophyll (1975-1990), DOC (1968), and $K_{\text {par }}(1975-1976)$ data were collected in different years, the calculated total diffuse attenuation coefficient is similar to the observed values from the Plymouth region, with fairly good agreement throughout the year (Figure $4 a$ ). Our ability to obtain $K_{\text {par }}$ estimates based on dissolved and particulate components of color from 1 year off Plymouth that, for the most part, match observed values of another year underscores the repetitive nature of the seasonal cycles of the color constituents. In Figure $4 a$ the imperfect fidelity of model computations and observations can be attributed to interannual variability and the inherent pitfalls of the averaging process (Table 1).

This is not the case off Roscoff in Figure $4 b$. Although the yearly carbon fixation may be twice as large in the Roscoff area than off Plymouth $\left(300 \mathrm{~g} \mathrm{C} \mathrm{m}^{-2} \mathrm{yr}^{-1}\right.$ versus $150 \mathrm{~g} \mathrm{C}$ $\mathrm{m}^{-2} \mathrm{yr}^{-1}$ ) [Boalch et al., 1978; Wafar et al., 1983], the surviving phytoplankton pigments only contribute up to $16 \%$

Table 3. Monthly Photosynthetically Active Radiation at Noon Crossing the Sea Surface of the Western English Channel Assuming a Marine Aerosol and a Visibility of $23 \mathrm{~km}$

\begin{tabular}{|c|c|c|c|c|c|c|c|c|c|c|c|c|c|}
\hline \multicolumn{14}{|c|}{ Wavelength, nm } \\
\hline & $400-424$ & $425-449$ & $450-474$ & $475-499$ & $500-524$ & $525-549$ & $550-574$ & $575-599$ & $600-624$ & $625-649$ & $650-674$ & $675-700$ & Sum \\
\hline Jan. & 28.4 & 32.9 & 41.5 & 44.0 & 45.3 & 48.2 & 49.7 & 49.6 & 52.3 & 53.3 & 41.9 & 63.0 & 550.3 \\
\hline Feb. & 44.1 & 51.4 & 64.6 & 68.3 & 70.1 & 74.5 & 76.8 & 76.9 & 80.3 & 81.2 & 63.5 & 95.4 & 847.1 \\
\hline March & 66.5 & 76.8 & 96.0 & 100.9 & 103.2 & 109.5 & 112.9 & 113.4 & 117.2 & 117.9 & 91.7 & 138.1 & 1244.2 \\
\hline April & 86.0 & 98.9 & 122.9 & 128.6 & 131.2 & 139.1 & 143.4 & 144.2 & 148.3 & 148.7 & 115.4 & 173.9 & 1580.7 \\
\hline May & 97.5 & 111.6 & 138.4 & 144.5 & 147.2 & 155.9 & 160.7 & 161.7 & 165.8 & 166.1 & 128.8 & 194.2 & 1772.4 \\
\hline June & î́i.7 & 116.3 & 144.0 & 150.3 & 153.0 & 162.0 & 166.9 & 168.1 & 172.2 & 172.4 & 133.6 & 201.5 & 1841.8 \\
\hline July & 100.0 & 114.4 & 141.7 & 147.9 & 150.5 & 159.5 & 164.3 & 165.4 & 169.5 & 169.7 & 131.5 & 198.4 & 1812.9 \\
\hline Aug. & 92.2 & 105.7 & 131.2 & 137.1 & 139.7 & 148.0 & 152.6 & 153.5 & 157.6 & 157.9 & 122.5 & 184.6 & 1682.5 \\
\hline Sep. & 77.1 & 88.8 & 110.6 & 115.9 & 118.3 & 125.5 & 129.4 & 130.1 & 134.0 & 134.6 & 104.5 & 157.5 & 1426.3 \\
\hline Oct. & 55.9 & 64.8 & 81.3 & 85.6 & 87.7 & 93.1 & 96.0 & 96.3 & 99.9 & 100.7 & 78.5 & 118.1 & 1058.0 \\
\hline Nov. & 35.9 & 41.7 & 52.6 & 55.7 & 57.3 & 61.0 & 62.8 & 62.8 & 65.9 & 66.8 & 52.4 & 78.7 & 693.6 \\
\hline Dec. & 25.2 & 29.2 & 36.8 & 39.0 & 40.1 & 42.7 & 43.9 & 43.8 & 46.4 & 47.4 & 37.3 & 56.1 & 487.9 \\
\hline
\end{tabular}

Radiation is in $(\lambda)\left(\mu E \mathrm{~m}^{-2} \mathrm{~s}^{-1} \mathrm{~nm}^{-1}\right)$. After Gregg and Carder [1990]. 


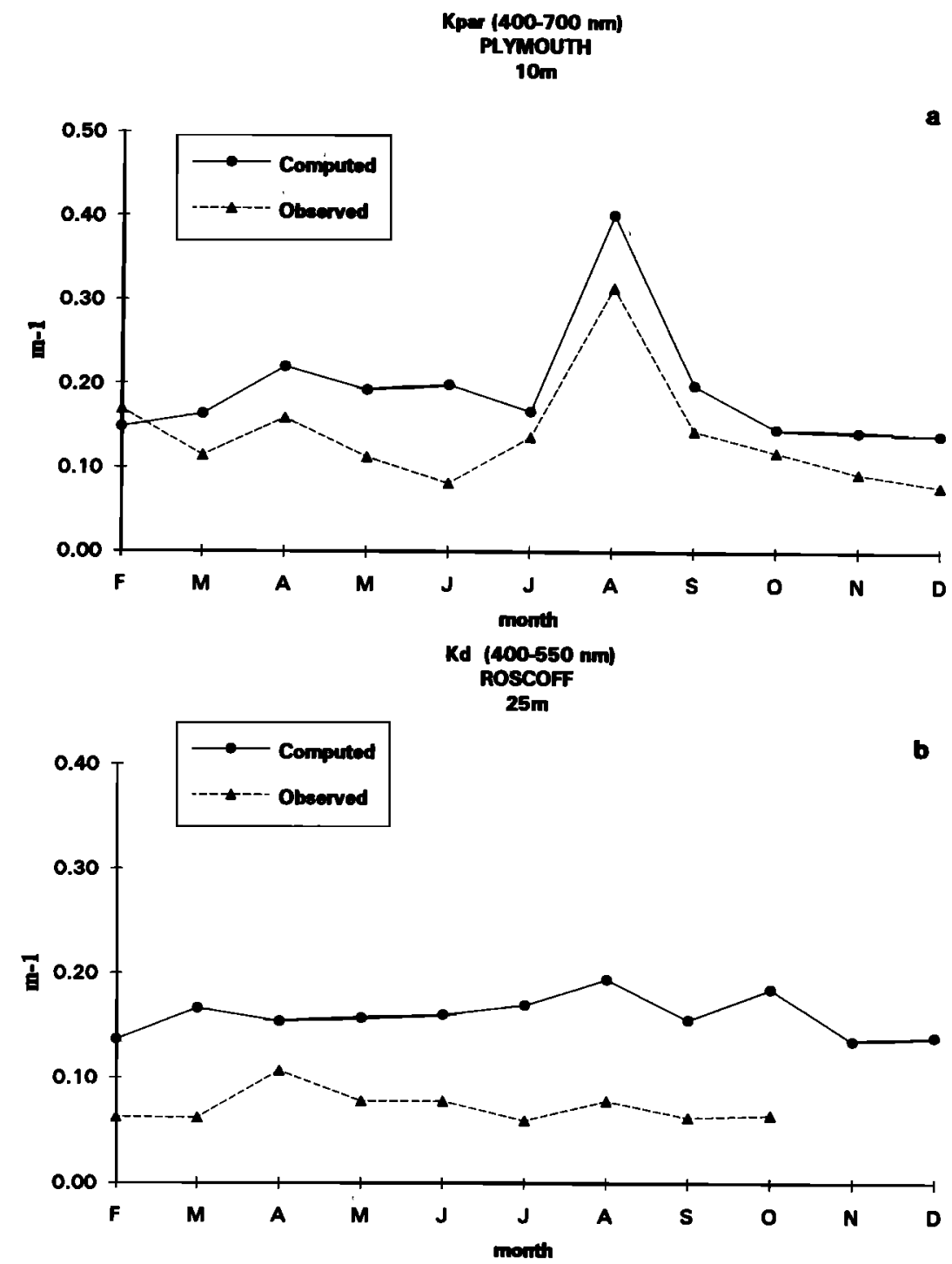

Figure 4. The seasonal variation of computed total $K_{\mathrm{PAR}}\left(\mathrm{m}^{-1}\right)$ and of its water $K_{W}\left(\mathrm{~m}^{-1}\right)$, colored dissolved organic carbon (CDOC) $K_{Y}\left(\mathrm{~m}^{-1}\right)$, chlorophyll $K_{C}\left(\mathrm{~m}^{-1}\right)$ components off $(\mathrm{a}, \mathrm{c})$ Plymouth and (b, d) Roscoff. The computed $K_{\text {PAR }}\left(\mathrm{m}^{-1}\right)$ is derived from our model, and the observed $K_{\mathrm{PAR}}\left(\mathrm{m}^{-1}\right)$ is the mean presented in Table 1.

of the attenuation of visible light here (Figure $4 d$ ). CDOC amounts to $19-30 \%$ of the color signal, that is, twice that off Plymouth (Figure 4c), with maxima found 1-2 months after small blooms of the phytoplankton [Wafar et al., 1984]. Water itself provides $71 \%$ of the light attenuation at its seasonal maximum.

However, the computed $K_{d}$ is not in as good agreement (Figure $4 b$ ) with those means observed during 1985 [Sournia et al., 1987]; our model predicts about a twofold higher $\boldsymbol{K}_{d}$. It is possible that the measured $K_{d}$ values were anomalously low in 1985 compared to 1981 . At similar chlorophyll stocks of $0.5-1.0 \mathrm{mg} \mathrm{chl} \mathrm{m} \mathrm{m}^{-3}$, for example, $K_{d}(520)$ was found to be $0.09 \mathrm{~m}^{-1}$ off Roscoff on July 16, 1981 (measured with the same type of instrument by Holligan et al. [1983]), as opposed to a $K_{d}(520)$ of $0.05 \mathrm{~m}^{-1}$ measured from July 9-24, 1985 [Sournia et al., 1987], that is, almost twofold less. The specific absorption of pure water at $520 \mathrm{~nm}$ [Smith and Baker, 1981] is $0.0477 \mathrm{~m}^{-1}$, or a $K_{W}(520)$ of $0.0575 \mathrm{~m}^{-1}$, suggesting very clear waters off Roscoff; ship shadowing at the surface could cause reduction of the measured $K_{d}(520)$ in 1985.

The DOC values obtained from shipboard measurements and those calculated from the differences between the CZCS and in situ pigment data, using (5) and (7), are displayed in Figure 5. The excess pigment off Plymouth (Table 2) was positive 8 of the 11 months, ranging from 2 to $77 \%$ of the in situ + excess pigments (total CZCS estimate), with CDOC presumably contributing to a monthly mean of $46 \%$ of the stock estimated by the CZCS. Off Roscoff, excess pigment (Table 2) was positive 10 of the 11 months, ranging from 22 to $87 \%$ of the in situ + excess pigments, with CDOC now amounting to a similar monthly mean of $48 \%$ of the algal biomass seen by the CZCS.

The predicted and observed DOC concentrations are much closer off Plymouth (Figure $5 a$ ) than off Roscoff (Figure $5 b$ ), however, despite the larger percentage contribution of CDOC in French waters. Because the measured seston was low off Roscoff [Sournia et al., 1987], our results 

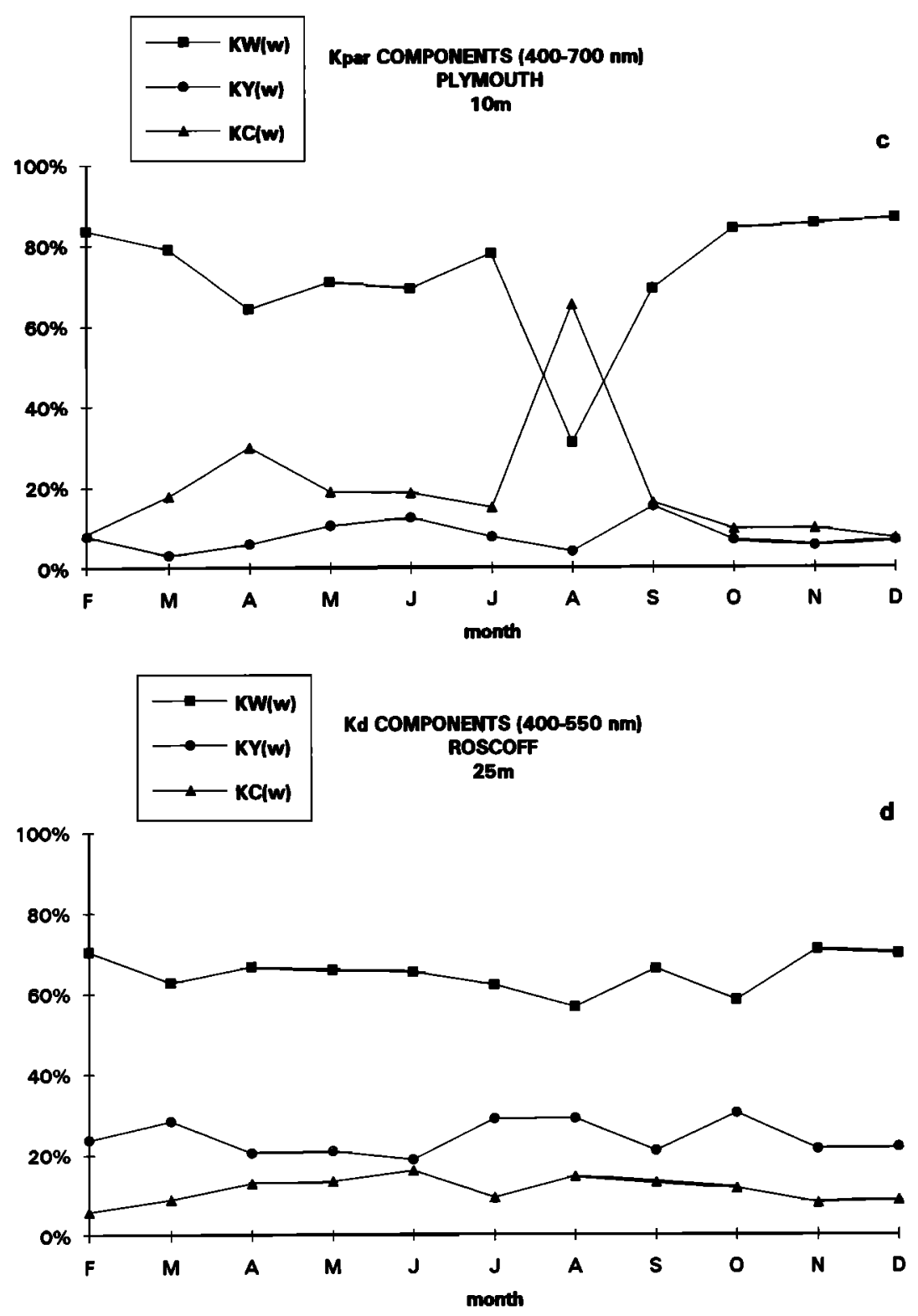

Figure 4. (continued)

suggest that (1) an unknown amount of terrestrial CDOC, with a different specific absorption coefficient may be present, (2) the ratios of marine fulvic and humic acids may be different between the two ecosystems, and/or (3) a larger fraction of nonabsorbing DOC may be present within the tidally mixed waters off France, since the same mean $a_{p h(443)}^{*}$ was used in (7).

\section{Discussion}

Terrestrial DOC within riverine influxes amounted to only $25 \%$ of the in situ DOC production in Morlaix Bay, adjacent to Roscoff [Wafar et al., 1989]. Furthermore, yearly salinity range of 34.95-35.30 psu off Roscoff [Wafar et al., 1983], similar to other waters of the western English Channel [Armstrong et al., 1970], may rule out major freshwater sources of CDOC. In any event a tenfold larger specific absorption coefficient for terrestrial CDOC [Blough et al., 1993] would lead to even smaller estimates of DOC from (7) and (5), presumably eliminating this option, since $80 \%$ of terrestrial DOC is humic substances, that is, CDOC [Mantoura and Woodward, 1983].

Marine CDOC may be derived from cell lysis of phytoplankton pigments [Harvey et al., 1983; Carder et al., 1989] during grazing and decomposition, since neither humic and fulvic acids nor their unsaturated lipid precursors [Harvey et al., 1984] have yet to be found among the extracellular release products of phytoplankton [Lancelot, 1984]. If verified by future measurements, the larger amounts of CDOC off Plymouth and more nonabsorbing DOC off Roscoff imply differences in the way these food webs process particulate organic carbon (POC) and DOC.

A smaller grazing stress off Roscoff would allow the greater increments of annual primary production and less production of CDOC from sloppy herbivores [Jumars et al., 1989]. Here the seasonal maximum of zooplankton biomass over the upper $25 \mathrm{~m}$ was $1.2 \mathrm{~g} \mathrm{dw} \mathrm{m}^{-2}$, or about $0.54 \mathrm{~g} \mathrm{C}$

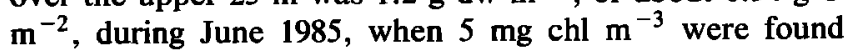


[Sournia et al., 1987]. A copepod growth rate of $13 \%$ body weight per day [Vidal and Smith, 1986], with an assimilation efficiency of $70 \%$ and a $50 \%$ respiration loss, suggests an ingestion demand of $37 \%$ body weight per day, that is, about $0.20 \mathrm{~g} \mathrm{C} \mathrm{m}^{-2} \mathrm{~d}^{-1}$ at station B. With a $C / \mathrm{chl}$ ratio of 45 , the maximum daily grazing stress on diatoms off Roscoff might thus be $\sim 4 \%$ of the phytoplankton biomass.

During the spring bloom off Plymouth, as much as $50 \%$ of the phytoplankton biomass is instead consumed daily by copepods [Davies et al., 1992], that is, a quantity tenfold greater than off Roscoff. At the same time, a similar diatom excretion rate of about $4 \%$ of the daily primary production, in both regions [Reid et al., 1990], would lead to twice as much nonabsorbing DOC released off Roscoff than Plymouth, as a consequence of the twofold greater annual photosynthesis. Benthic macroflora may also release polysaccharides within the shallow, tidally mixed waters. These possible contrasts in production of CDOC and nonabsorbing DOC off Roscoff and Plymouth are reflected in the seasonal patterns of the differences between the in situ and remotely sensed pigments (Figures 2 and 3).

With fallout of POC from the April spring bloom off Plymouth (Figure 6a), for example, a near-bottom pool of DOC evolves above the 70-m isobath after a 1-month time lag (Figure $6 b$ ), similar to the seasonal cycle of surface waters (Table 1). We do not show the vertical structure of DOC off Roscoff, since there it is homogeneous. Fall overturn of the stratified Plymouth waters then resupplies the
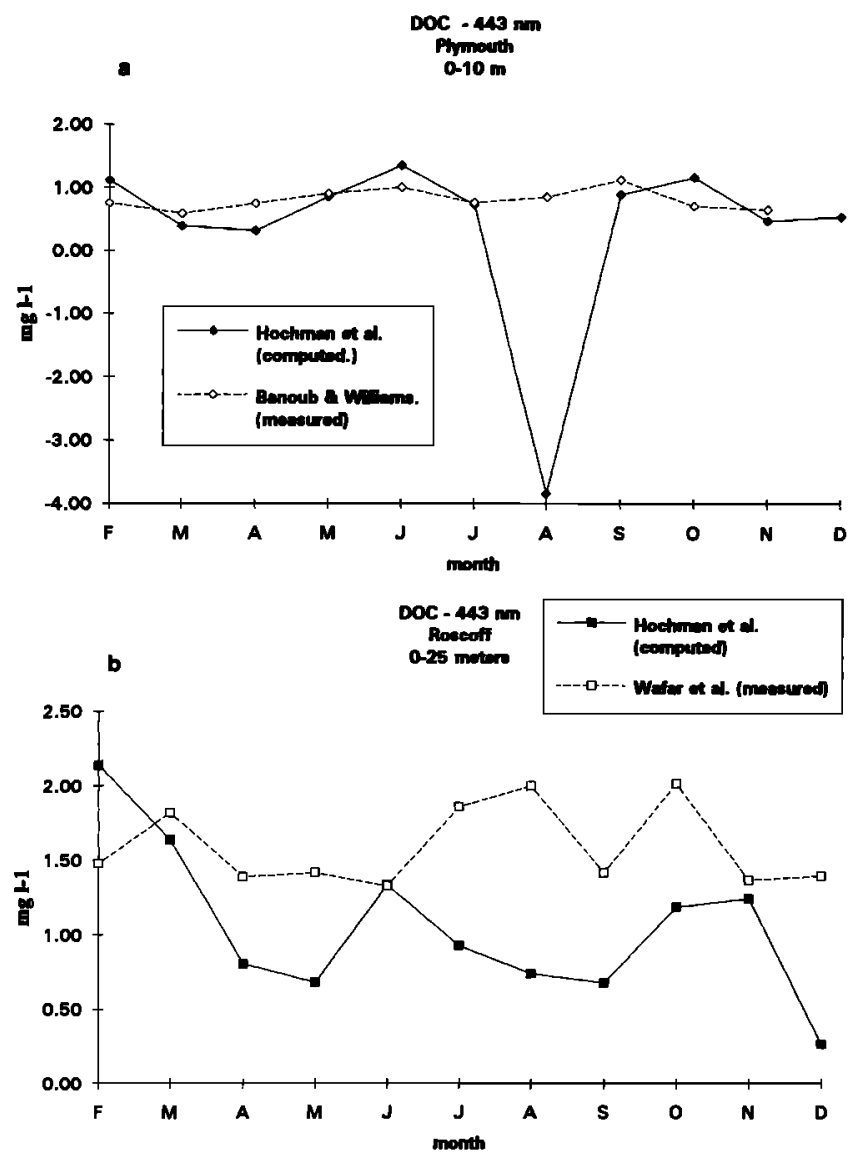

Figure 5. A comparison of the computed and measured DOC (mg L ${ }^{-1}$ ) over a depth of (a) 0-10 m off Plymouth and (b) $0-25 \mathrm{~m}$ off Roscoff.
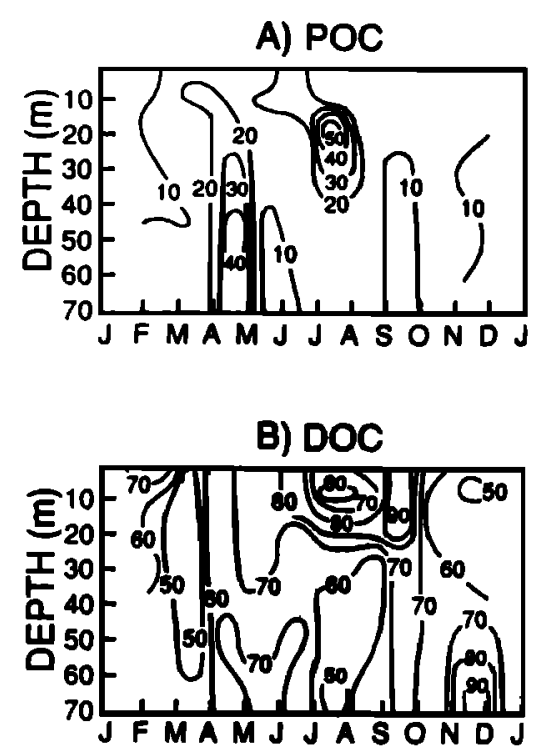

Figure 6. The seasonal cycles of (a) particulate organic carbon (micrometers) and (b) dissolved organic carbon (micrometers) above the 70-m isobath off Plymouth in 1968 (data from Banoub and Williams [1973]).

DOC (Figure $6 b$ ) to the October euphotic zone, where the strong CDOC signal was sensed by the CZCS (Figure 2).

Within the Plymouth region (Figure 2) the CZCS data show March-April variations that are similar to the in situ ranges of pigment, reflecting particulate stocks (Figure 6a) of the diatoms. During late spring and early summer the CZCS data have a wider range of values than shipboard pigment measurements, suggesting greater CDOC contamination (Figure 6b) after cell lysis by grazers. By August the in situ pigments and CZCS pigment values have approximately the same range, reflecting again stocks of phytoplankton, but now these stocks are those of the subsequent dinoflagellate blooms [Jordan and Joint, 1984].

After the fall overturn, however, the CZCS range of pigments in October is much larger than the in situ one off Plymouth (Figure 2), exhibiting significant CDOC contamination of the remotely sensed color signal, as the DOC stored in the aphotic zone is mixed to the surface (Figure $6 b$ ). Off Roscoff the CZCS range in October (Figure 3 ) is instead half that of Plymouth and similar to the in situ range of pigments within the tidally mixed waters.

Spring blooms of 2-3 $\mathrm{mg} \mathrm{chl} \mathrm{m}^{-3}$ of the prymnesiophyte, Phaeocystis pouchetii, are now found at station E [Davies et al., 1992] but rarely at station $B$. They secrete as much as $40 \%$ of their daily photosynthate as dissolved organic matter, compared to the $4 \%$ released by diatoms [Reid et al., 1990]. If, like the post-1966 blooms of summer dinoflagellates, the abundance of $\boldsymbol{P}$. pouchetii increases off Plymouth, more amounts of nonabsorbing DOC may be found there in the future, providing a testable hypothesis for our grazing/ excretion scenario.

Spring blooms of $\boldsymbol{P}$. pouchetii, for example, have increased between 1973 and 1985 [Cadee and Hegeman, 1986] to as much as $25 \mathrm{mg} \mathrm{chl} \mathrm{m} \mathrm{m}^{-3}$ along the Belgian [Lancelot and Mathot, 1987], Dutch [Veldhuis et al., 1986], and German [Batje and Michaelis, 1986] coasts. There, subsequent MayJune stocks of 5-6 mg DOC $\mathrm{L}^{-1}$ are found after their blooms 
[Billen and Fontigny, 1987; Eberlein et al., 1985]. The amounts of CDOC within these large transient pools of coastal DOC in the southern North Sea and their contribution to remotely sensed ocean color signals are unknown.

\section{Conclusions}

We are pleased that data of different years from the western English Channel can be used to assess the contribution of marine CDOC to the contamination of remotely sensed color signals. It is about $47 \%$ of the apparent pigment off Roscoff and Plymouth, similar to our conclusions on the impact of terrestrial CDOC within the Orinoco River plume [Hochman et al., 1994].

Both the Plymouth and Roscoff time series exhibit periods when only one measurement was available for the in situ data, however. The large and rapid spatial variations of pigment that occur in the English Channel (Plates 1 and 2) reinforce the need for both satellite imagery and in situ measurements of both CDOC and its chemical constituents, as well as chlorophyll and its phaeopigments, in order to better understand the bio-optical dynamics of this and other coastal regions.

Specifically, our inferences about the different food webs and roles of CDOC and nonabsorbing DOC off Plymouth and Roscoff hinge on unmeasured amounts of humic and fulvic substances from possible terrestrial and marine DOM sources. Clearly, continued interpretation of CDOC sensed by future satellites, that is, with an additional band at $412 \mathrm{~nm}$ on the sea-viewing wide-field-of-view sensor (SeaWiFS), requires concurrent time series of the color components, particularly DOC and CDOC stocks of marine and terrestrial origin, at sampling intervals similar to those of satellite overpasses.

Acknowledgments. This research was funded by the National Aeronautics and Space Administration and the Office of Naval Research under grants NAGW-3459, NAGW-3483, NAGW-465, and ONR N00014-89-J-1091. We thank Gene Feldman at the Goddard Space Flight Center (NASA, Greenbelt, Maryland) for providing the data for the CZCS archive located at USF.

\section{References}

Armstrong, F. A., E. I. Butler, and G. T. Boalch, Hydrographic and nutrient surveys in the western English Channel during 1961 and 1962, J. Mar. Biol. Assoc. U.K., 50, 883-905, 1970.

Banoub, M. W., and P. J. Williams, Seasonal changes in the organic forms of carbon, nitrogen, and phosphorous in sea water at E1 in the English Channel during 1968, J. Mar. Biol. Assoc. U.K., 53, 695-703, 1973.

Batje, M., and H. Michaelis, Phaeocystis pouchetii blooms in East Frisian coastal waters (German Bight, North Sea), Mar. Biol. Berlin, 93, 21-27, 1986.

Billen, G., and A. Fontigny, Dynamics of a Phaeocystis-dominated bloom in Belgian waters, II, Bacterioplankton dynamics, Mar. Ecol. Prog. Ser., 37, 249-257, 1987.

Blough, N. V., O. C. Zafiriou, and J. Bonilla, Optical absorption spectra of waters from the Orinoco River outflow: Terrestrial input of colored organic matter to the Caribbean, J. Geophys. Res., 98, 2271-2278, 1993.

Boalch, G. T., D. S. Harbour, and E. I. Butler, Seasonal phytoplankton production in the western English Channel 1964-1974, J. Mar. Biol. Assoc. U.K., 58, 943-953, 1978.

Cadee, G. C., and J. Hegeman, Seasonal and annual variations of Phaeocystis pouchetii (Haptophyceae) in the westernmost inlet of the Wadden Sea during the 1973 to 1985 period, Neth.J. Sea Res., 20, 29-36, 1986.
Carder, K. L., R. G. Steward, G. R. Harvey, and P. B. Ortner, Marine humic and fulvic acids: Their effects on remote sensing of ocean chlorophyll, Limnol, Oceanogr., 34, 68-81, 1989.

Davies, A. G., I. De Madariaga, B. Bautista, E. Fernandez, D. S. Harbour, P. Serret, and P. R. Tranter, The ecology of a coastal Phaeocystis bloom in the northwestern English Channel in 1990, J. Mar. Biol. Assoc. U.K., 72, 691-708, 1992.

Dixon, G. K., and P. M. Holligan, Studies on the growth and nitrogen assimilation of the bloom dinoflagellate Gyrodimium aureolum Hulburt, J. Plankton Res., 11, 105-118, 1989.

Duursma, E. K., The production of dissolved organic matter in the sea, as related to the primary gross production of organic matter, Neth. J. Sea Res., 2, 85-94, 1963.

Eberlein, K., M. T. Leal, K. D. Hammer, and W. Hickel, Dissolved organic substances during a Phaeocystis pouchetii bloom in the German Bight, Mar. Biol. Berlin, 89, 311-326, 1985.

Feldman, G., et al., Ocean color, availability of the global data set, Eos Trans. $A G U, 70,634-635,640-641,1989$.

Gordon, H. R., and A. Y. Morel, Remote Assessment of Ocean Color for Interpretation of Satellite Visible Imagery, pp. 1-114, Springer-Verlag, New York, 1983.

Gordon, H. R., D. K. Clark, J. W. Brown, O. B. Brown, R. H. Evans, and W. W. Broenkow, Phytoplankton pigment concentrations in the Middle Atlantic Bight: Comparison of ship determinations and CZCS estimates, Appl. Opt., 22, 20-35, 1983.

Gregg, W. W., and K. L. Carder, A simple spectral solar irradiance model for cloudless maritime atmospheres, Limnol. Oceanogr., $35,1657-1675,1990$.

Harvey, G. R., D. A. Boran, L. A. Chesal, and J. N. Takar, The structure of marine fulvic acid and humic acids, Mar. Chem., 12, 119-133, 1983.

Harvey, G. R., D. A. Boran, S. R. Piotrowicz, and C. P. Weisel, Synthesis of marine humic substances from unsaturated lipids, Nature, 313, 474-475, 1984.

Hochman, H. T., F. E. Muller-Karger, and J. J. Walsh, Interpretation of the color signature of the Orinoco River plume, $J$. Geophys. Res., 99, 7443-7455, 1994.

Hoepffner, N., and S. Sathyendranath, Bio-optical characteristics of coastal waters: Absorption spectra of phytoplankton and pigment distribution in the western North Atlantic, Limnol. Oceanogr., 37, 1660-1679, 1992.

Holligan, P. M., and D. S. Harbour, The vertical distribution and succession of phytoplankton in the western English Channel in 1975 and 1976, J. Mar. Biol. Assoc. U.K., 75, 1075-1093, 1977.

Holligan, P. M., M. Viollier, C. Dupouy, and J. Aiken, Satellite studies on the distributions of chlorophyll and dinoflagellate blooms in the western English Channel, Cont. Shelf Res., 2, 81-96, 1983.

Holligan, P. M., R. P. Harris, R. C. Newell, D. S. Harbour, R. N. Head, E. A. Linley, M. I. Lucas, P. R. Tranter, and C. M. Weekley, Vertical distribution and partitioning of organic carbon in mixed, frontal, and stratified waters of the English Channel, Mar. Ecol. Prog. Ser., 14, 111-127, 1984.

International Council for the Exploration of the Sea, Mean Monthly Temperature and Salinity of the Surface Layer of the North Sea and Adjacent Waters From 1905 to 1954, Charlottenlund, Copenhagen, 1962.

Jerlov, N. G., Marine Optics, Elsevier, New York, 1976.

Joint, I. R., N. J. Owens, and A. J. Pomroy, Seasonal production of photosynthetic picoplankton and nanoplankton in the Celtic Sea, Mar. Ecol. Prog. Ser., 28, 251-258, 1986.

Jordan, M. B., and I, R. Joint, Studies on phytoplankton distribution and primary production in the western English Channel in 1980 and 1981, Cont. Shelf Res., 3, 25-34, 1984.

Jumars, P. A., D. L. Penry, J. A. Baross, M. J. Perry, and B. W. Frost, Closing the microbial loop: Dissolved carbon pathway to heterotrophic bacteria form incomplete ingestion, digestion, and absorption in animals, Deep Sea Res., Part A, 36, 483-496, 1989.

Klein, B., and A. Sournia, A daily study of the diatom spring bloom at Roscoff (France) in 1985, II, Phytoplankton pigment composition studied by HPLC analysis, Mar. Ecol. Prog. Ser., 37, 265-275, 1987.

Laane, R. W., Sources of dissolved organic carbon in the EmsDollart estuary: The rivers and phytoplankton, Neth.J. Sea Res., 15, 331-339, 1982.

Lancelot, C., Extracellular release of small and large molecules by 
phytoplankton in the southern Bight of the North Sea, Estuarine Coastal Shelf Sci., 18, 65-77, 1984.

Lancelot, C., and S. Mathot, Dynamics of a Phaeocystis-dominated spring bloom in Belgian coastal waters, I, Phytoplankton activities and related parameters, Mar. Ecol. Prog. Ser., 37, 239-248, 1987.

Le Corre, P., S. L'Helguen, and M. Wafer, Nitrogen source for uptake by Gyrodinium of. aureolum in a tidal front, Limnol. Oceanogr., 38, 446-451, 1993.

Malone, T. C., T. S. Hopkins, P. G. Falkowski, and T. E. Whitledge, Production and transport of phytoplankton biomass over the continental shelf of the New York Bight, Cont. Shelf Res., 1, 305-337, 1983.

Mantoura, R. F., and E. M. Woodward, Conservative behavior of riverine dissolved organic carbon in the Severn Estuary: Chemical and geochemical implications, Geochim. Cosmochim. Acta, 47, 1293-1309, 1983.

Martin-Jezequel, M., Facteurs hyrologiques et phytoplancton en Baie de Moralix (Manche Occidentale), Hydrobiologia, 102, 131$143,1983$.

Menzel, D. W., and R. F. Vaccaro, The measurement of dissolved organic and particulate carbon in seawater, Limnol. Oceanogr., 9, 138-142, 1964.

Morel, A., and L. Prieur, Analysis of variations in ocean color, Limnol. Oceanogr., 22, 708-722, 1977.

Muller-Karger, F. E., Remote sensing of marine pollution: A challenge for the 1990s, Mar. Pollut. Bull., 25, 1-4, 54-60, 1992.

Okami, N., M. Kishino, S. Sugihara, N. Takematsu, and S. Unoki, Analysis of ocean color spectra (III)-Measurements of optical properties of sea water, J. Oceanogr. Soc. Jpn., 38, 362-372, 1982.

Partensky, F., and A. Sournia, Le dinoflagelle Gyrodinium cf. aureolum dans le plancton de l'Atlantique Nord: Identification, ecologie, toxicite, Cryptogam. Algol., 7, 251-275, 1986.

Pingree, R. D., P. M. Holligan, G. T. Mardell, and R. N. Head, The influence of physical stability on spring, summer, and autumn phytoplankton blooms in the Celtic Sea, J. Mar. Biol. Assoc. U.K., 56, 845-873, 1976.

Reid, P. C., C. Lancelot, W. W. Gieskes, E. Hagmeier, and G. Weichart, Phytoplankton of the North Sea and its dynamics: A review, Neth. J. Sea Res., 26, 295-331, 1990.

Sathyendranath, $S$., and T. Platt, The spectral irradiance field at the surface and in the interior of the ocean: A model for applications in oceanography and remote sensing, J. Geophys. Res., 93, 9270-9280, 1988.
Sathyendranath, S., T. Platt, C. M. Caverhill, R. E. Warnock, and M. R. Lewis, Remote sensing of oceanic primary production: Computations using a spectral model, Deep Sea Res., Part A, 36, 431-453, 1989.

Smith, R. S., and K. S. Baker, Optical properties of the clearest natural waters (200-800 nm), Appl. Opt., 20, 177-184, 1981.

Sournia, A., J. L. Birrien, J.-L. Douville, and M. Viollier, A daily study of the diatom spring bloom at Roscoff (France) in 1985, I, The spring bloom within the annual cycle, Estuarine Coastal Shelf Sci., 25, 355-367, 1987.

Veldhuis, M. J., W. Admiraal, and F. Colijn, Chemical and physiological changes of phytoplankton during the spring bloom, dominated by Phaeocystis pouchetii (Haptophyceae): Observations in Dutch coastal waters of the North Sea, Neth. J. Sea Res., 20, 49-60, 1986.

Vidal, J., and S. L. Smith, Biomass, growth, and development of populations of herbivorous zooplankton in the southeastern Bering Sea during spring, Deep Sea Res., Part A, 33, 523-556, 1986.

Wafar, M. V. M., P. Le Corre, and J.-L. Birrien, Nutrients and primary production in permanently well-mixed temperate coastal waters, Estuarine Coastal Shelf Sci., 17, 431-446, 1983.

Wafar, M. V. M., P. Le Corre, and J.-L. Birrien, Seasonal changes of dissolved organic matter $(C, N, P)$ in permanently well-mixed temperate waters, Limnol. Oceanogr., 29, 1127-1132, 1984.

Wafar, M. V. M., P. Le Corre, and J.-L. Birrien, Transport of carbon, nitrogen, and phosphorus in a Brittany river, France, Estuarine Coastal Shelf Sci., 29, 489-500, 1989.

Walsh, J. J., T. E. Whitledge, J. E. O'Reilly, W. C. Phoel, and A. F. Draxler, Nitrogen cycling within seasonally stratified and tidally mixed regions of the Mid-Atlantic Bight: The New York Shelf and Georges Bank, in Georges Bank, edited by R. H. Backus, pp. 234-246, MIT Press, Cambridge, Mass., 1987.

Walsh, J. J., K. L. Carder, and F. E. Muller-Karger, Meridional fluxes of dissolved organic matter in the North Atlantic Ocean, $J$. Geophys. Res., 97, 15,625-15,637, 1992.

K. L. Carder, H. T. Hochman, F. E. Muller-Karger, and J. J. Walsh, Department of Marine Science, University of South Florida, St. Petersburg, FL 33701.

A. Sournia, Observatoire Oceanologique de Roscoff, Laboratoire de Geologie du Museum, 43 r. Buffon, 75005 Paris, France.

(Received April 28, 1994; revised October 5, 1994; accepted January 17, 1995.) 